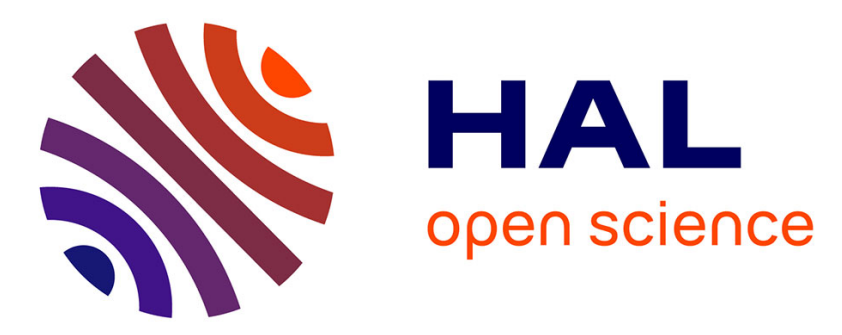

\title{
Glass ceramic for the vitrification of high level waste with a high molybdenum content
}

O. Pinet, J.-F. Hollebecque, I. Hugon, V. Debono, L. Campayo, C. Vallat, V. Lemaitre

\section{- To cite this version:}

O. Pinet, J.-F. Hollebecque, I. Hugon, V. Debono, L. Campayo, et al.. Glass ceramic for the vitrification of high level waste with a high molybdenum content. Journal of Nuclear Materials, 2017, 519, pp.121-127. 10.1016/j.jnucmat.2019.03.041 • cea-02421740

\section{HAL Id: cea-02421740 \\ https: / hal-cea.archives-ouvertes.fr/cea-02421740}

Submitted on 20 Dec 2019

HAL is a multi-disciplinary open access archive for the deposit and dissemination of scientific research documents, whether they are published or not. The documents may come from teaching and research institutions in France or abroad, or from public or private research centers.
L'archive ouverte pluridisciplinaire HAL, est destinée au dépôt et à la diffusion de documents scientifiques de niveau recherche, publiés ou non, émanant des établissements d'enseignement et de recherche français ou étrangers, des laboratoires publics ou privés. 


\title{
Glass ceramic for the vitrification of high level waste with a high molybdenum content
}

\author{
O. Pinet*, J-F. Hollebecque, I. Hugon, V. Debono, L. Campayo, C. Vallat, V. Lemaitre
}

CEA, DEN, DE2D, SEVT - Marcoule, F-30207 Bagnols sur Cèze, France

*Corresponding author: olivier.pinet@cea.fr

Keywords: nuclear waste, glass ceramic, high molybdenum content, vitrification, phase separation.

\begin{abstract}
Vitrification has been selected in France as the immobilization process for high-level waste arising from spent fuel reprocessing. Several high-level waste solutions from the reprocessing of legacy UMo spent fuel, used in gas cooled reactors, have been stored in the AREVA La Hague facility in stainless steel tanks since the mid-1960s. A special glass-ceramic formulation has been developed and qualified through lab and pilot testing to meet standard waste acceptance criteria for the final disposal of the UMo waste. The Cold Crucible Induction Melter (CCIM) was selected for the vitrification of this particularly hard-to-process waste stream because it could not be reasonably processed in the standard hot induction melters currently used at the La Hague vitrification facilities: the waste has a high molybdenum and phosphorous content which makes it corrosive and also requires a special high temperature glass formulation to obtain sufficiently high waste loading factors, higher than $10 \mathrm{wt} \%$ in Molybdenum oxide. Molybdenum is known to be sparingly soluble in
\end{abstract}


conventional borosilicate glass. The formulated glass-ceramic matrix comprises a major vitreous phase containing secondary phase particles less than $100 \mu \mathrm{m}$ in diameter. These are formed by phase separation and crystallization as the molten glass cools in the canister. The physical and microstructural properties of the UMo glass in the solid and liquid states are reported here. Evolution of microstructure as a function of the sample position in the canister was investigated, given the sensitivity of the crystallization process to the cooling profile. The chemical durability of the UMo glass-ceramic was also studied. The feasibility of this process has been demonstrated in a full-scale pilot facility with inactive surrogate solutions.

\section{Introduction}

Glass has several advantages for nuclear waste containment: it guarantees the stability of the waste package for a very long time and significantly reduces its volume $[1,2]$. Vitrification has been used for several decades in France, the United Kingdom, Russia and the United States to immobilize high-level nuclear waste from spent commercial fuel or legacy waste [3]. The criteria to be considered for glasses developed in this context are that they should minimize waste volumes and offer ease of processing and good long term stability. These three objectives define the desired final glass properties, glass melt properties and process parameters such as the melting temperature, additives specificity and capacity. The most decisive properties are often the homogeneity and leaching behavior of the glass and the viscosity of the melt at temperatures compatible with the selected vitrification process. If the waste contained in the glass is particularly radioactive, the thermal stability and stability under irradiation of the glass should also be considered. Mixed alkali aluminum borosilicates are typically preferred because they can durably incorporate a wide range of radioactive elements and are relatively easy to form. [1-3] 
UMo waste solutions are fission products from the reprocessing of some spent nuclear fuel from graphite gas reactors. Their specificity is that they contain large amounts of molybdenum and phosphorous oxide (respectively $137 \mathrm{~g} \cdot \mathrm{L}^{-1}$ and $42 \mathrm{~g} \cdot \mathrm{L}^{-1}$ ), which account for nearly $90 \%$ of the total mineral oxide content of the solution. Their radioactivity is typically $\sim 2.2 \mathrm{PBq} \cdot \mathrm{L}^{-1}$. The molybdenum and phosphorus loading capacity of the containment glass is therefore critical. Homogeneous borosilicate glasses cannot be prepared with molybdenum oxide contents of more than a few mass percent [4-6], so other types of glass have been investigated for this purpose [7,8]. In particular, durable, easily fabricated glass-ceramic matrices have been developed at the CEA with higher molybdenum and phosphorous capacities [9].

The selected glass has to represent the best possible compromise between the three objectives stated above. The material presented in this paper for UMo-waste containment is a glass ceramic melted at $1250{ }^{\circ} \mathrm{C}$ using a cold crucible melter not feasible using a hot crucible melter. This choice results from the screening of a wide range of candidate glass materials with high molybdenum and phosphorous contents, which have previously been melted at high temperature and characterized after cooling [9]. Here, we describe the preparation and characterization of a glass ceramic that can incorporate more than $10 \mathrm{wt} \% \mathrm{MoO}_{3}$. This glass ceramic was tested using inactive surrogate solutions at the laboratory scale and in a full-scale pilot facility. Microstructural and rheological properties, electrical conductivity and durability of the $10 \mathrm{wt} \%$ of $\mathrm{MoO}_{3}$ glass ceramic were also investigated.

\section{Experimental}

\subsection{UMo glass ceramic compositions}

The compositions of the simulated containment glass ceramic melted at the laboratory scale (L-UMo) and full industrial scale (F-UMo) are presented in Table 1. These 
compositions differ from that envisaged for the active glass in that technetium, uranium and samarium are replaced respectively by manganese, neodymium and lanthanum. Considering the low uncertainties on the weighing of the precursors, their purity, and the volatility of the species involved, the effective composition of the L-UMo glass was taken to be equal to its theoretical composition. For the F-UMo glass, the values shown in Table 1 were obtained by X-ray fluorescence spectroscopy; the average of measurements performed on four samples with different cooling profiles is shown, alongside the maximum difference between the four when this exceeded $0.01 \mathrm{wt} \%$.

\subsection{Glass preparation}

The L-UMo glass was prepared using boric acid $\left(\mathrm{H}_{3} \mathrm{BO}_{3}\right)$ and oxides $\left(\mathrm{SiO}_{2}, \mathrm{Al}_{2} \mathrm{O}_{3}\right.$, $\mathrm{MoO}_{3}, \mathrm{MgO}, \mathrm{CaO}, \mathrm{Fe}_{2} \mathrm{O}_{3}, \mathrm{NiO}, \mathrm{Co}_{2} \mathrm{O}_{3}, \mathrm{Cr}_{2} \mathrm{O}_{3}, \mathrm{ZnO}, \mathrm{ZrO}_{2}, \mathrm{Y}_{2} \mathrm{O}_{3}, \mathrm{La}_{2} \mathrm{O} 3, \mathrm{Nd}_{2} \mathrm{O}_{3}, \mathrm{Pr}_{6} \mathrm{O}_{11}$, $\mathrm{CeO}_{2}, \mathrm{RuO}_{2}, \mathrm{SnO}_{2}, \mathrm{TeO}_{2}$, carbonates $\left(\mathrm{Na}_{2} \mathrm{CO}_{3}, \mathrm{Li}_{2} \mathrm{CO}_{3}\right)$, phosphate $\left(\mathrm{AlPO}_{4}\right)$, nitrates $\left(\mathrm{Ba}\left(\mathrm{NO}_{3}\right)_{2}, \mathrm{Sr}\left(\mathrm{NO}_{3}\right)_{2}, \mathrm{CsNO}_{3}, \mathrm{Rh}\left(\mathrm{NO}_{3}\right)_{3}\right)$ precursors. The difference between the two compositions is that the F-UMo glass does not contain any manganese (simulating technetium) or rhodium. The raw materials were mixed in a Turbula blender then added gradually to an insulated Joule-heated platinum-rhodium crucible. Once all the raw materials were added and the temperature was stabilized at $1250{ }^{\circ} \mathrm{C}$, the molten mixture was stirred mechanically for $3 \mathrm{~h}$. About $200 \mathrm{~g}$ of the melt was poured into an alumina crucible preheated to $1250{ }^{\circ} \mathrm{C}$ and then cooled in a furnace at $100{ }^{\circ} \mathrm{C} \cdot \mathrm{h}^{-1}$ from 1250 to $700{ }^{\circ} \mathrm{C}$ and then at 25 ${ }^{\circ} \mathrm{C} \cdot \mathrm{h}^{-1}$ down to room temperature. A $100 \mathrm{~g}$ portion of the melt was poured into a graphite crucible and annealed by slowly decreasing its temperature near the glass transition temperature determined by DTA at $518{ }^{\circ} \mathrm{C}$. The rest of the melt was then plate-quenched. The objective of these three cooling scenarios was to investigate the range of the possible cooling profiles occurring between the edges and the middle of an industrial waste glass canister. 
The F-UMo glass was prepared in Marcoule using a full-scale inactive pilot, model of the cold crucible induction melter operating in the AREVA La Hague facility (Fig. 1) [10], which operates as follows. The initial solution is fed into the calciner heated at about $400^{\circ} \mathrm{C}$. The calcinate is then mixed with glass frit in the cold crucible melter, which is continuously supplied with calcinate and intermittently with a borosilicate glass frit especially manufactured to reach the targeted composition after dissolution of simulated waste. Glass frit composition is (wt \%): 48,50 $\mathrm{SiO}_{2} ; 17,47 \mathrm{~B}_{2} \mathrm{O}_{3} ; 10,54 \mathrm{Na}_{2} \mathrm{O} ; 7,57 \mathrm{ZnO} ; 3,80 \mathrm{ZrO}_{2} ; 7,69$ $\mathrm{CaO} ; 0,27 \mathrm{Li}_{2} \mathrm{O} ; 0,31 \mathrm{CoO} ; 0,31 \mathrm{NiO}$. The glass in the crucible is directly heated by the eddy currents generated by the inductor surrounding the shell. The main parameters monitored during the melting process are (target values in parenthesis) the temperature $\left(1250{ }^{\circ} \mathrm{C}\right)$, stirrer speed $(50 \mathrm{rpm})$ and the gas flow rate through the injectors $\left(400 \mathrm{NL} \cdot \mathrm{h}^{-1}\right)[11]$. The nominal throughput is $45 \mathrm{~kg} \cdot \mathrm{h}^{-1}$ and each canister is filled with two $200 \mathrm{~kg}$ pours. The glass samples for this study were taken from four positions in the canister (shown in Fig. 2, positions 1-4): near the bottom, in the middle, at the edge, at the interface between two pourings.

\subsection{Microstructural analysis}

The microstructure of the glass samples was observed by scanning electron microscopy (SEM) using a ZEISS Supra 55 device operating at $15 \mathrm{kV}$ and a probe current of $1 \mathrm{nA}$ equipped with an EDS spectrometer Brücker AXS X-Flash Detector 4010. The objective is to determine whether crystallization and/or phase separation has occurred. These analyses were complemented by X-ray diffraction (XRD) measurements (Philips PANanalytical $X^{\prime}$ Pert) to identify any crystalline phases.

\subsection{Rheological measurements}

The high-temperature rheological behavior of the L-UMo glass was characterized using a Searle-type coaxial-cylinder viscometer. A stationary platinum-rhodium crucible with 
an inside diameter of $27 \mathrm{~mm}$ is filled in an auxiliary furnace with the molten glass. A platinum-rhodium rotor $9 \mathrm{~mm}$ in diameter is placed in the middle of the glass melt and rotated using a Rheometric Scientific rheometer that measures the shear stress applied by the molten glass as a function of rotation speed. Measurements are performed at decreasing temperatures starting at a temperature high enough to guarantee the homogeneity of the melt. At high temperatures, the glass melt is homogeneous and behaves as a Newtonian fluid, i.e. the shear stress is proportional to the rotation speed and the viscosity can be determined by linear regression of the shear stress against the strain rate. Rheological behavior changes as temperature decreases and the melt becomes inhomogeneous [12,13]. After cooling, the glass was heated once more up to $1300{ }^{\circ} \mathrm{C}$ to assess whether the Newtonian rheological behavior was retrieved after a period spent below the phase separation temperature. The uncertainty on the viscosity measurements was estimated to be less than $10 \%$ considering results of measurements performed on a reference glass in the same range of viscosity and temperature with the same technique and device before and after the measurements performed on L-UMo glass. 


\subsection{Electrical resistivity measurements}

Electrical conductivity measurements in the molten state were performed by impedance spectroscopy using a four probe electrode cell. The setup for these measurements is described in detail elsewhere $[14,15]$. The melt was heated to a temperature high enough for its viscosity to be below $30 \mathrm{dPa} \cdot \mathrm{s}$, to avoid bending or damaging the platinum electrodes. The electrical conductivity of the L-UMo glass was measured in $10{ }^{\circ} \mathrm{C}$ steps from 1300 down to $1150{ }^{\circ} \mathrm{C}$; the cooling rate was $120{ }^{\circ} \mathrm{C} \cdot \mathrm{h}^{-1}$. The four-probe cell was calibrated at room temperature using aqueous $\mathrm{KCl}$ solutions with an electrical conductivity close to that of the molten oxide studied. The measurements at $1250{ }^{\circ} \mathrm{C}$ carry a $20 \%$ uncertainty considering results performed with the same equipment on a reference glass of same range of resistivity in the concerned range of temperature and comparison with results obtained with other devices on this same reference glass.

\subsection{Durability tests}

Chemical durability of the glass samples was tested in Soxhlet mode in pure water at $100{ }^{\circ} \mathrm{C}$ using a polished coupon [16] with a total geometric surface area of $\sim 10 \mathrm{~cm}^{2}$. The samples tested in this way were those of the annealed and slowly-cooled L-UMo glass and those taken from positions 1, 2 and 3 in the canister for the F-UMo glass (as shown in Fig. 2). These were expected to differ most in terms of their cooling profiles. The leached surface area was considered to be equal to the geometric surface area of the coupon. The test lasted 14 days. The elemental content of the leaching solution was measured after 1, 2, 3, 7, 10 and 14 days by inductively coupled plasma atomic emission spectroscopy to determine the amount of boron, sodium, silicon and molybdenum lost from each sample and thus the normalized loss of these elements according to time in $\mathrm{g} \cdot \mathrm{m}^{-2}$ is calculated. If 
normalized loss increases linearly with time at the same rate for all the four elements, then a corresponding initial dissolution rate in $\mathrm{g} \cdot \mathrm{m}^{-2} \cdot \mathrm{j}^{-1}, r_{0}$, can be determined.

$r_{0}=\frac{C_{i} V}{f_{i} S}$

where $C_{i}$ is concentration of element $i$ in the leaching solution $\left(g . L^{-1}\right), V$ the volume of the leaching solution $(\mathrm{L}), \mathrm{f}_{\mathrm{i}}$ the mass fraction of the element in the glass (unitless), and $\mathrm{S}$ the surface area of the sample $\left(\mathrm{m}^{2}\right)$.

\section{Results}

\subsection{Microstructural analysis}

The L-UMo and F-UMo glass ceramics have similar microstructures, with secondary phases dispersed within an opaque borosilicate glass matrix. The secondary phases mostly consist of "beads" a few nanometers to a hundred micrometers diameter. The smaller beads (less than $5 \mu \mathrm{m}$ in diameter) appear homogeneous on the micrometer scale and mainly contain molybdenum, phosphorus, calcium, zinc and sodium. In the larger beads (up to $100 \mu \mathrm{m}$ in diameter), different crystalline or vitreous phases can be identified by SEM, namely calcium molybdate, calcium and zinc phosphates, and an interstitial vitreous borosilicate phase. The same microstructure is observed for all the samples regardless of their cooling profile or location in the canister. The difference between the different L-UMo and F-UMo samples lies in the relative proportions of homogeneous and multiphase beads and the size of the latter. In the plate-quenched L-UMo sample, the secondary-phase beads are mostly homogeneous (Fig. 3(a,b)) whereas in the slowly cooled L-UMo glass, mostly multiphase beads are observed (Fig. 3(c)). A number of dispersed ruthenium and rhodium particles a few micrometers diameter are also observed. The F-UMo samples contain a mixture of homogeneous and 
multiphase beads in relative proportions that depend on the location of the samples in the canister, i.e. on their cooling profiles.

The XRD data recorded for these samples show that they are mainly amorphous, with the only detected crystalline phase being powellite $\left(\mathrm{CaMoO}_{4}\right)$. Zinc phosphate and Calcium phosphate are amorphous or low-crystalized phases. Similar diffractograms are obtained for all the samples.

\subsection{Rheological behavior}

The Newtonian behavior of the L-UMo melt above $1180{ }^{\circ} \mathrm{C}$ was investigated by comparing the temperature dependence of the viscosity with the Vogel-Fulcher-Tammann equation (Fig. 4),

$$
\log (\boldsymbol{\eta})=A+\frac{B}{\left(\mathbf{T}-\mathbf{T}_{\mathbf{0}}\right)}
$$

where $\eta$ is the viscosity of the glass at temperature $\mathrm{T}\left({ }^{\circ} \mathrm{C}\right) . \mathrm{A}, \mathrm{B}$ and $\mathrm{T}_{0}$ are adjustment constants. The viscosity of the melt at $1250{ }^{\circ} \mathrm{C}$ was found to be $41 \pm 5 \mathrm{dPa} \cdot \mathrm{s}$. Fig. 4 shows that the molten glass becomes inhomogeneous between 1150 and $1180{ }^{\circ} \mathrm{C}$, the latter temperature being the highest at which Newtonian behavior consistent with the VogelFulcher-Tammann equation was detected.

\subsection{Electrical resistivity measurements}

Fig. 5 shows the temperature dependence of the electrical resistivity of the L-UMo melt. The uncertainty determination on these values is considered to be less to $10 \%$ resulting from comparisons of results obtained with different laboratory devices on the same borosilicate glass in the range of temperature explored for this study. The value of 7 


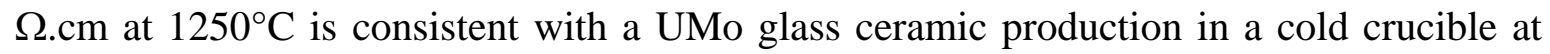
$1250^{\circ} \mathrm{C}$.

\subsection{Chemical durability}

Fig. 6 shows the amount $\left(\mathrm{g} \cdot \mathrm{m}^{-2}\right)$ of boron, silicon, sodium and molybdenum lost from the glass samples as a function of the leaching time. The amounts lost increase linearly with time at a similar rate for all four elements. Within the measurement uncertainties, the same results are obtained for all the samples. Table 2 lists the initial dissolution rates calculated for different samples from the normalized boron loss curves. The initial leaching dissolution rate obtained for these samples is $2.5 \pm 0,5 \mathrm{~g} \cdot \mathrm{m}^{-2} \cdot \mathrm{d}^{-1}$.

\section{Discussion}

At high temperatures, the L-UMo and F-UMo glass ceramics form a homogenous borosilicate melt with only ruthenium particles remaining undissolved [13]. This means that at the melting temperature $\left(1250{ }^{\circ} \mathrm{C}\right)$ at least $10.0 \mathrm{wt} \% \mathrm{MoO}_{3}$ and $3.1 \mathrm{wt} \% \mathrm{P}_{2} \mathrm{O}_{5}$ are solubilized in the borosilicate melt (see Table 1). During cooling, rheological data (Fig. 4) show that liquid-liquid phase separation occurs between 1080 and $1050{ }^{\circ} \mathrm{C}$ in the L-UMo glass. These results are also supported by a previous study in which rheometric results were compared with in situ measurements of glass melt homogeneity at high temperatures or after the samples were quenched rapidly [13]. This loss of homogeneity, described in detail by Schuller et al. [12], results in the formation of beads dispersed in the borosilicate matrix. Our data show that the beads mainly contain molybdenum, calcium, phosphorus and smaller amounts of zinc. Quantitative analysis by wavelength-dispersive X-ray spectroscopy performed on this type of beads formed in a similar UMo glass has shown that they also contain a large amount of boron in an interstitial silicate phase [17]. 
This phase separation can logically be attributed to the high molybdenum and phosphorous contents of the glass because, among all the elements in the glass, these two belong to the least soluble in borosilicate glass [4-7]. This then implies that below 1080$1050^{\circ} \mathrm{C}$, the solubilities of molybdenum and phosphorous oxides are lower than 10.0 and $3.1 \mathrm{wt} \%$, respectively. As the solubility of these elements in the "glass" melt decreases with temperature, more beads are formed. In a second step, these beads are the site of crystallization and separation of a secondary phase. The size of the beads and thus the microstructure of the glass depend on the cooling rate (slower cooling rates leads to larger particles and more secondary phase), as observed for the different UMo glass ceramic samples prepared in this study (Fig. 3). In these glass ceramics, previous analyses performed on a derived UMo glass ceramic formulation has shown that molybdenum is mainly incorporated in the beads and that there is little molybdenum or phosphorous in the surrounding glass [17]. Furthermore, in a derived "glass", an equivalent molybdenum oxide solubility $(\sim 10 \mathrm{wt} \%)$ has been estimated from the rate of formation of powellite crystals quantified by Rietveld analysis at different cooling rates [18]. These results also suggest that powellite forms even if the UMo melt is plate-quenched and that the beads formed in fast-cooled samples are more homogeneous than in those cooled more slowly [18].

The UMo glass ceramic prepared in a full scale pilot vitrification facility with a surrogate UMo solution and glass frit (F-UMo) shows the same microstructure as the samples prepared from powders at the laboratory scale (L-UMo). The secondary phase beads vary slightly in size depending on the location of the sample in the canister (Fig. 2), in accordance with the expected variations in cooling rates. These beads, up to several hundred micrometers diameter, are embedded in a borosilicate glass matrix. An alteration model for this matrix has already been proposed [17]. It has been demonstrated that if the 
surrounding glass is durable, the leaching behaviour of the whole glass matrix is finally governed by that of the surrounding glass [17]. In the case of UMo glass ceramic, the surrounding glass composition is close to those of durable peralkaline glass. The leaching rates measured here at $100^{\circ} \mathrm{C}$ for F-UMo samples (Fig. 6) are similar to those of nuclear borosilicate glass. Given the durability, size and concentration of the secondary phase beads, an additional release early in the leaching tests could have been expected but was not observed. This could be because the secondary phase is efficiently retained in the surrounding matrix [18]. The concentration and size of the secondary phase particles may also be too low to generate significantly measurable releases [19]. These results highlight the value of a well-controlled microstructure in this context.

This UMo glass ceramic provides a solution to durably contain radioactive waste rich in molybdenum. Its waste volume reduction factor is at least four times better than conventional homogeneous nuclear glass. Its fabrication on an industrial scale requires heating to temperatures above the phase separation temperature, which mainly depends on the chosen molybdenum and phosphorus contents. The tests reported here, performed in a full scale pilot facility, of a two-step vitrification process using a calciner and a cold crucible show that the process can be adapted to the industrial scale. The glass melt is also shown to have the electrical properties required for preparation in a cold crucible furnace. Similar glass ceramics devoted to other forms of high level waste are also being developed elsewhere [20], the objective being, like in our study, to increase the loading rate in waste and thus reduce the number of glass packages that need to be produced. 


\section{Conclusions}

A major objective of nuclear glass formulation studies is to minimize the volume of the final waste. Glass ceramics are thus advantageous because they can hold more waste than homogeneous glasses. The UMo glass ceramic studied here can incorporate substantially more (10 versus just a few wt $\%$ ) molybdenum oxide than the homogeneous borosilicate glass that is currently used for waste with high level waste containment.

The vitrification of nuclear waste with this glass ceramic has been shown to be feasible by cold crucible induction melting, which allows the melt to be heated to temperatures high enough for it to remain homogeneous, above the phase separation and crystallization temperatures. These temperatures have been determined to be below $1180^{\circ} \mathrm{C}$ for the considered UMo glass ceramic. After crystallization during cooling, the resulting glass ceramic is macroscopically homogeneous. The type of secondary phases does not change according to the location in the canister.

The durability of this type of waste containment matrix is typically governed by the durability of the surrounding glass. Considering the case of the UMo glass ceramic, the initial dissolution rate is $2.5 \mathrm{~g} \cdot \mathrm{m}^{-2} \cdot \mathrm{d}^{-1}$ at $100^{\circ} \mathrm{C}$. But this issue needs to be carefully investigated on a case-by-case basis.

This glass ceramic is now implemented in the cold crucible vitrification line of La Hague industrial vitrification facility [21].

Finally, note that there is considerable latitude to optimize this type of matrix, notably in terms of minimization of the final waste volume for other types of nuclear wastes.

\section{Acknowledgement}


The authors gratefully acknowledge the support and cooperation of AREVA for this research.

\section{References}

[1] E. Vernaz, S. Gin, C. Veyer, Waste Glass, in: Konings R.J.M., (ed.), Comprehensive Nuclear Materials 5 (2012), pp. 451-483.

[2] S. Gin, A. Abdelouas, L.J. Criscenti, W.L. Ebert, K. Ferrand, T. Geisler, M.T. Harrison, Y. Inagaki, S. Mitsui, K.T. Mueller, J.C. Marra, C.G. Pantano, E.M. Pierce, J.V. Ryan, J.M. Schofield, C.I. Steefel, J.D. Vienna, An International Initiative on Long-term Behavior of High-level Nuclear Waste Glass, Mater. Today 16 (2013) 243-248.

[3] I.W. Donald, B.L. Metcalfe, R.N.J. Taylor, The Immobilization of High Level Radioactive Wastes Using Ceramics and Glasses, J. Mater. Sci. 32 (1997) 5851-5887.

[4] E. Nicoleau, S. Schuller, F. Angeli, T. Charpentier, P. Jollivet, A. Le Gac, M. Fournier, A. Mesbah, F. Vasconcelos, Phase Separation and Crystallization Effects on the Structure and Durability of Molybdenum Borosilicate Glass, J. Non-Cryst. Solids 427 (2015) 120-133.

[5] D. Caurant, O. Majérus, E. Fadel, A. Quintas, C. Gervais, T. Charpentier, D. Neuville, Structural Investigations of Borosilicate Glasses Containing $\mathrm{MoO}_{3}$ by MAS NMR and Raman Spectroscopies, J. Nucl. Mater. 396 (2010) 94-101.

[6] B.F. Dunnett, N.R. Gribble, R. Short, C.J. Steele and A.D. Riley, $\mathrm{MoO}_{3}$ Incorporation in Magnesium Aluminosilicate Glasses, Glass Technol.: Eur. J. Glass Sci. Technol. A 53 (2012), 166-171. 
[7] O. Pinet, E. Baudrey, C. Fillet, J.L. Dussossoy, J.F. Hollebecque, Influence of Redox on Waste Containment Glass Properties: Case of a Borosilicate Glass Containing 16 wt \% of $\mathrm{MoO}_{3}$, Glass Technology volume of the XIX International Congress on Glass Processing (2002), 572 -573.

[8] S.Tan, M.I. Ojovan, N.C. Hyatt, R.J. Hand, $\mathrm{MoO}_{3}$ Incorporation in Magnesium Aluminosilicate Glasses, J. Nucl. Mater. 458 (2015) 335-342.

[9] O. Pinet, J.L. Dussossoy, C. David, C. Fillet, Glass Containment Matrix for Radioactive Waste Containing High Amount of Molybdenum and Phosphorous, J. Nucl. Mater. 377 (2008) 307-312.

[10] E. Vernaz, J. Bruezière, History of Nuclear Waste Glass in France, Proc. Mater. Sci. 7 (2014) 3-9.

[11] O. Pinet, J.F. Hollebecque, F. Angeli, P. Gruber, Vitrification of Molybdenum-Rich High-Level Solutions by the Cold Crucible Melter Process - 11502, WM2011 Conference, March 2011.

[12] S. Schuller, O. Pinet, A. Grandjean, T. Blisson, Phase Separation and Crystallization of Borosilicate Glass Enriched in $\mathrm{MoO}_{3}, \mathrm{P}_{2} \mathrm{O}_{5}, \mathrm{ZrO}_{2}$ and $\mathrm{CaO}$, J. of Non-Cryst. Solids 354 (2008) 296-300.

[13] S. Schuller, O. Pinet, B. Penelon, Liquid- Liquid Phase Separation Process in Borosilicate Liquids Enriched in Molybdenum and Phosphorus Oxides, J. Am. Ceram. Soc. 94 (2011) 447-454. 
[14] C. Simonnet, J. Phalippou, M. Malki, A. Grandjean, Electrical Conductivity Measurements of Oxides from Molten State to Glassy State, Rev. Sci. Instrum. 74 (2003) 2805-2810.

[15] M. Malki, P. Echegut, Ionic Conductivity in Glasses and Melts (Up to $1950 \mathrm{~K}$ ): Application to the $\mathrm{CaO}-\mathrm{SiO}_{2}$ System, Int. J. Thermophys. 25 (2004) 1495-1503.

[16] ISO 16797:2004, Chemical Durability Test — Soxhlet-mode Chemical Durability Test — Application to Vitrified Matrixes for High-level Radioactive Waste, April 2004

[17] O. Pinet, A. Grandjean, P. Frugier, H. Rabiller, S. Poissonnet, Leaching Behavior of a Polyphase Glass-ceramic Containment Matrix, J. of Non-Cryst. Solids 352 (2006) 3095-3102.

[18] N. Henry, P. Deniard, S. Jobic, R. Brec, C. Fillet, F. Bart, A. Grandjean, O. Pinet, Heat Treatments Versus Microstructure in a Molybdenum-rich Borosilicate J. Non-Cryst. Solids 333 (2004) 199-205.

[19] K. Brinkman, K. Fox, J. Marra, J. Reppert, J. Crum, M. Tang, Single Phase Melt Processed Powellite (Ba,Ca) $\mathrm{MoO}_{4}$ for the Immobilization of Mo-rich Nuclear Waste, J. Alloys Compd. 551 (2013) 136-142.

[20] J. Crum, V. Maio, J. McCloy, C. Scott, B. Riley, B. Benefiel, J. Vienna, K. Archibald, C. Rodriguez, V. Rutledge, Z. Zhu, J. Ryan, M. Olszta, Cold Crucible Induction Melter Studies for Making Glass Ceramic Waste Forms: A Feasibility Assessment, J. Nucl. Mater. 444 (2014) 481-492.

[21] R. Didierlaurent, J.F. Hollebecque, O. Pinet, E. Leveel, C. Veyer, I. Trévisan, C. Roussel, S. Philippe, UMo Solutions Processing in La Hague Cold Crucible Induction Melter: the Feedback from the First Years of Operation - 16376, WM2016 Conference, March 2016. 



\section{Table 1}

Composition (in wt\%) of the glass ceramics prepared at the laboratory scale (L-UMo) and in a full-scale pilot (F-UMo).

\begin{tabular}{|c|c|c|}
\hline & $\mathbf{L}^{-U_{M}}{ }^{\mathbf{a}}$ & F-UMo ${ }^{b}$ \\
\hline $\mathrm{SiO}_{2}$ & 38.67 & $39.68 \pm 0.07$ \\
\hline $\mathrm{Na}_{2} \mathrm{O}$ & 9.39 & $8.93 \pm 0.03$ \\
\hline $\mathbf{B}_{2} \mathbf{O}_{3}$ & 13.93 & $13.76 \pm 0.25$ \\
\hline $\mathrm{Al}_{2} \mathrm{O}_{3}$ & 7.07 & $7.49 \pm 0.02$ \\
\hline $\mathbf{P}_{2} \mathrm{O}_{5}$ & 3.08 & 3.36 \\
\hline $\mathrm{MoO}_{3}$ & 10.00 & $10.15 \pm 0.03$ \\
\hline $\mathrm{ZnO}$ & 6.03 & 5.82 \\
\hline $\mathrm{ZrO}_{2}$ & 3.27 & 3.32 \\
\hline $\mathrm{CaO}$ & 6.13 & $5.89 \pm 0.03$ \\
\hline $\mathbf{L i}_{2} \mathbf{O}$ & 0.21 & 0.16 \\
\hline $\mathrm{Cs}_{2} \mathrm{O}$ & 0.02 & 0.01 \\
\hline
\end{tabular}

$\mathrm{Nd}_{2} \mathrm{O}_{3}$ including simulated

$0.52 \quad 0.52$

$\mathrm{UO}_{2}$

$\mathrm{TcO}_{2}$ simulated by $\mathrm{MnO}_{2} \quad 0.04$

$\begin{array}{lll}\mathrm{NiO} & 0.28 & 0.30\end{array}$

$\begin{array}{lll}\mathrm{Cr}_{2} \mathrm{O}_{3} & 0.06 & 0.05\end{array}$

$\begin{array}{lll}\mathrm{SrO} & 0.05 & 0.03\end{array}$

$\begin{array}{lll}\text { CoO } & 0.25 & 0.26\end{array}$

$\begin{array}{lll}\mathbf{B a O} & 0.05 & 0.06\end{array}$

$\mathrm{La}_{2} \mathrm{O}_{3}$ including simulated

$\mathrm{Sm}_{2} \mathrm{O}_{3}$

$0.11 \quad 0.12$ 


$\begin{array}{ccc}\mathrm{CeO}_{2} & 0.12 & 0.12 \\ \mathrm{Pr}_{6} \mathrm{O}_{11} & 0.04 & 0.05 \\ \mathrm{TeO}_{2} & 0.06 & 0.03 \\ \mathrm{Fe}_{2} \mathrm{O}_{3} & 0.28 & 0.38 \\ \mathrm{MgO} & 0.14 & 0.30 \\ \mathrm{SnO}_{2} & 0.08 & 0.05 \\ \mathrm{RuO}_{2} & 0.10 & 0.10 \\ \mathbf{R h} & 0.04 & -\end{array}$

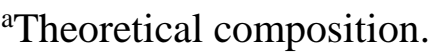

${ }^{b}$ Mean and maximum difference between measurements performed on four samples by X-ray fluorescence spectroscopy. 


\section{Table 2}

Initial dissolution rates at $100{ }^{\circ} \mathrm{C}$ from samples of UMo glass ceramic prepared at the laboratory scale (L-UMo) and in a full-scale vitrification pilot (F-UMo).

$\mathrm{r}_{0}$

$\left(\mathrm{g} \cdot \mathrm{m}^{-2} \cdot \mathrm{d}^{-1}\right)$

L-UMo

annealed

$2.3 \pm 0.4$

slowly cooled

$3.0 \pm 0.5$

F-UMo

1

$2.8 \pm 0.5$

2

$2.6 \pm 0.5$

4

$2.1 \pm 0.4$ 


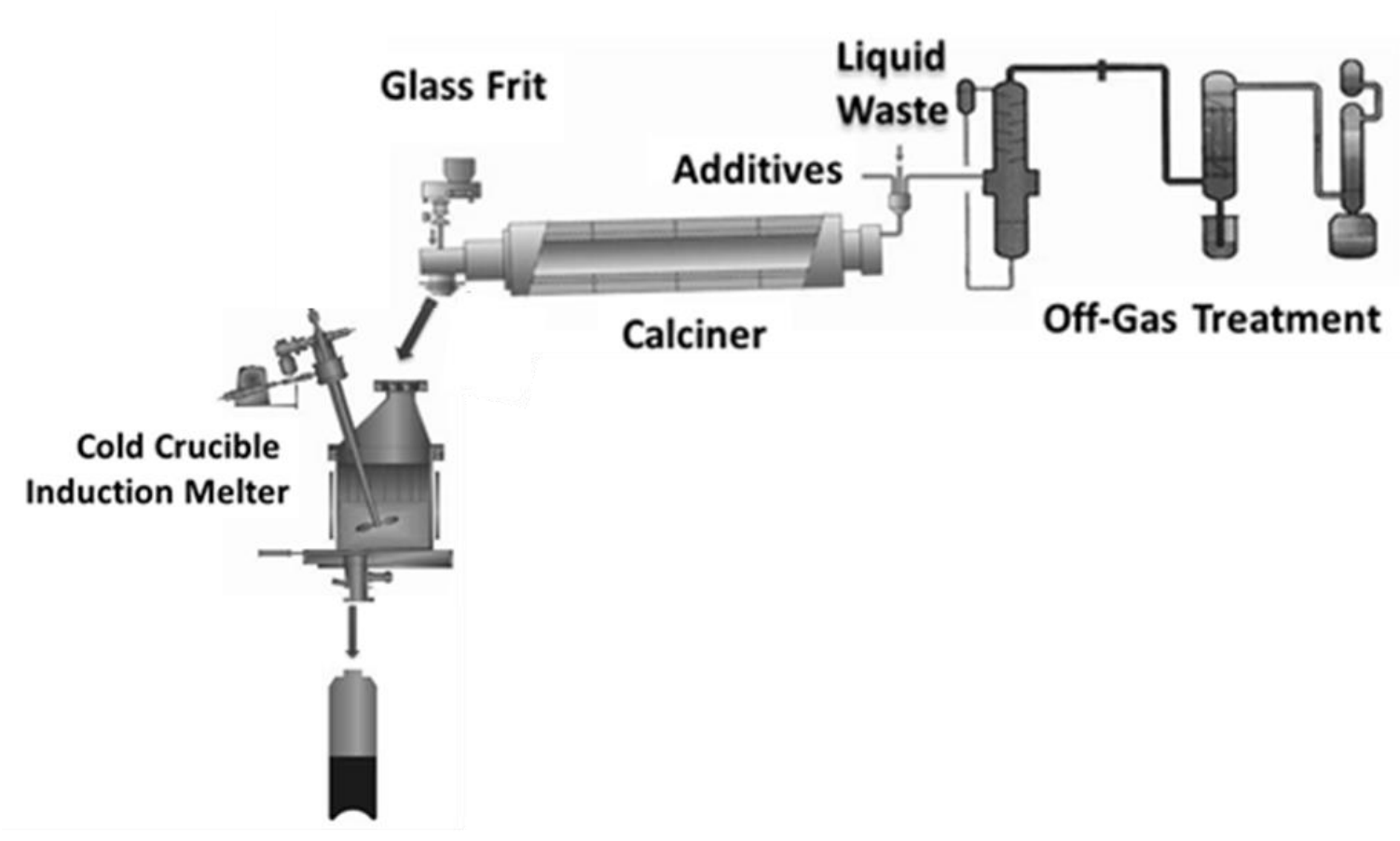

Fig. 1. Schematic diagram of the full scale vitrification pilot. 


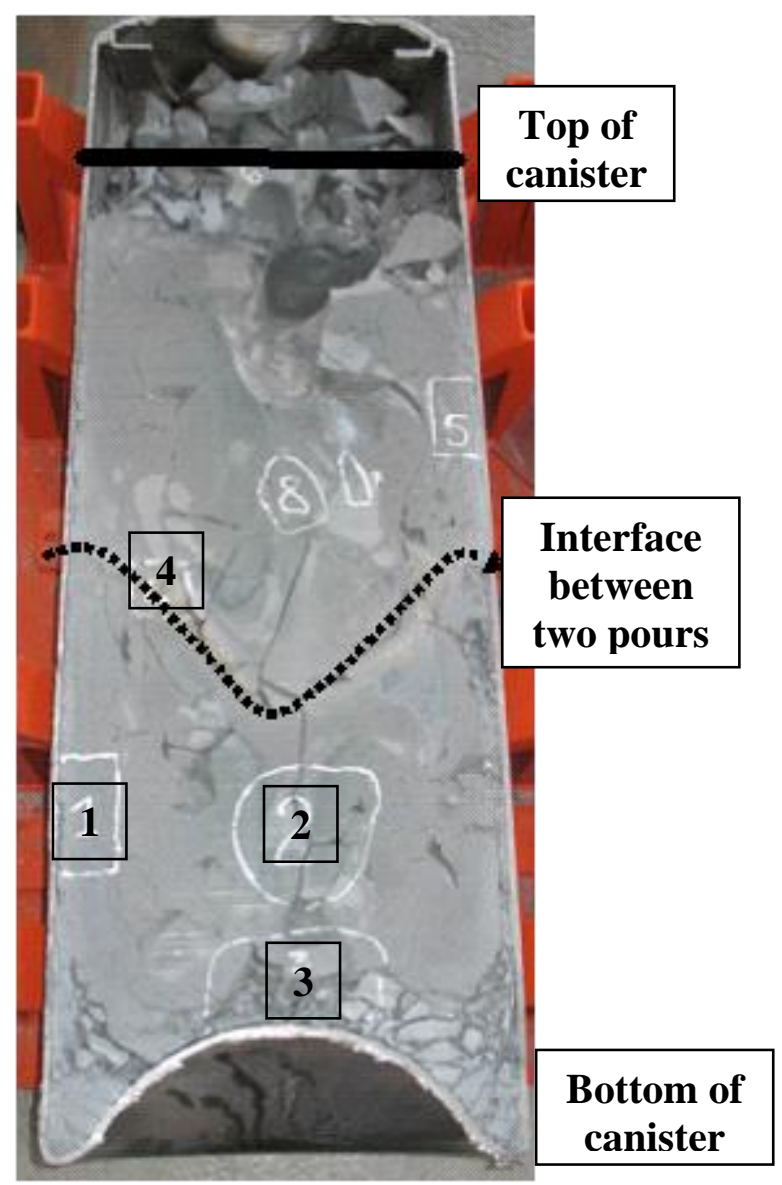

Fig. 2. Cross-sectional photograph of a standard glass canister for vitrified waste, showing the locations of the different samples of UMo glass ceramic (F-UMo, produced on an industrial scale) chosen for this study (positions 1-4). 

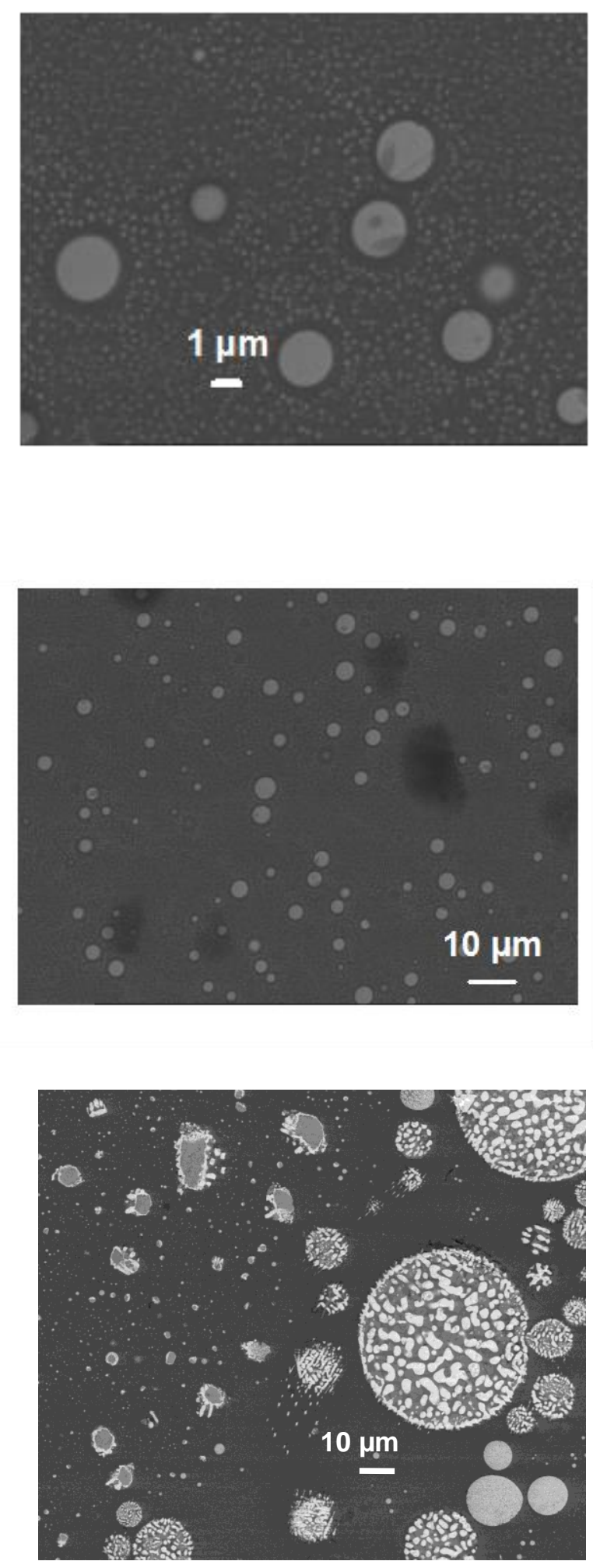

Fig. 3. Scanning electron microscopy micrographs of (a, b) plate-quenched and (c) slowly cooled samples of the U-Mo glass ceramic prepared on the laboratory scale (L-UMo). 


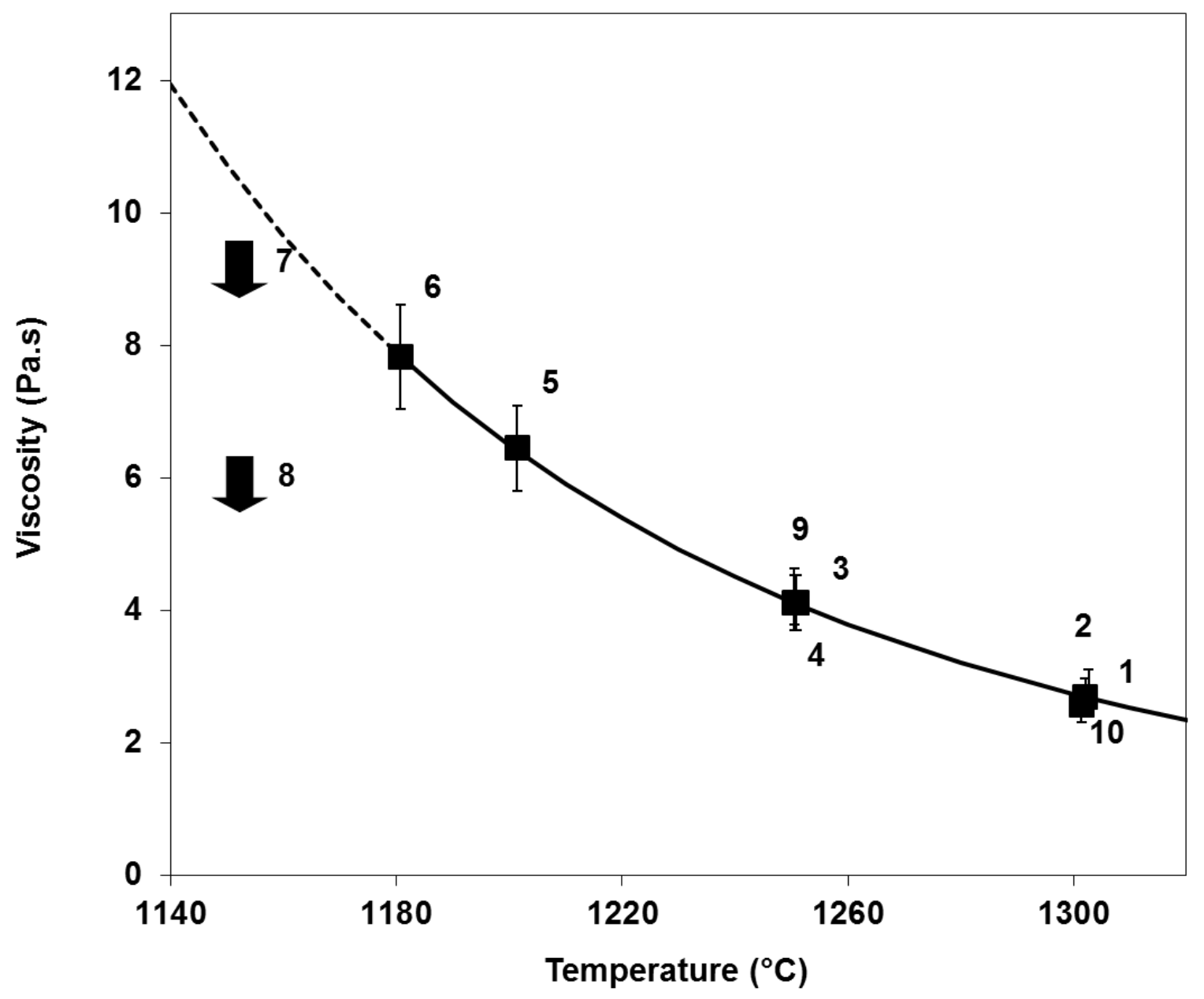

Fig. 4. Viscosity of the L-UMo melt (laboratory scale sample) as a function of temperature. The numbers indicate the order of the measurements, the arrows that non-Newtonian rheological behavior was detected. 


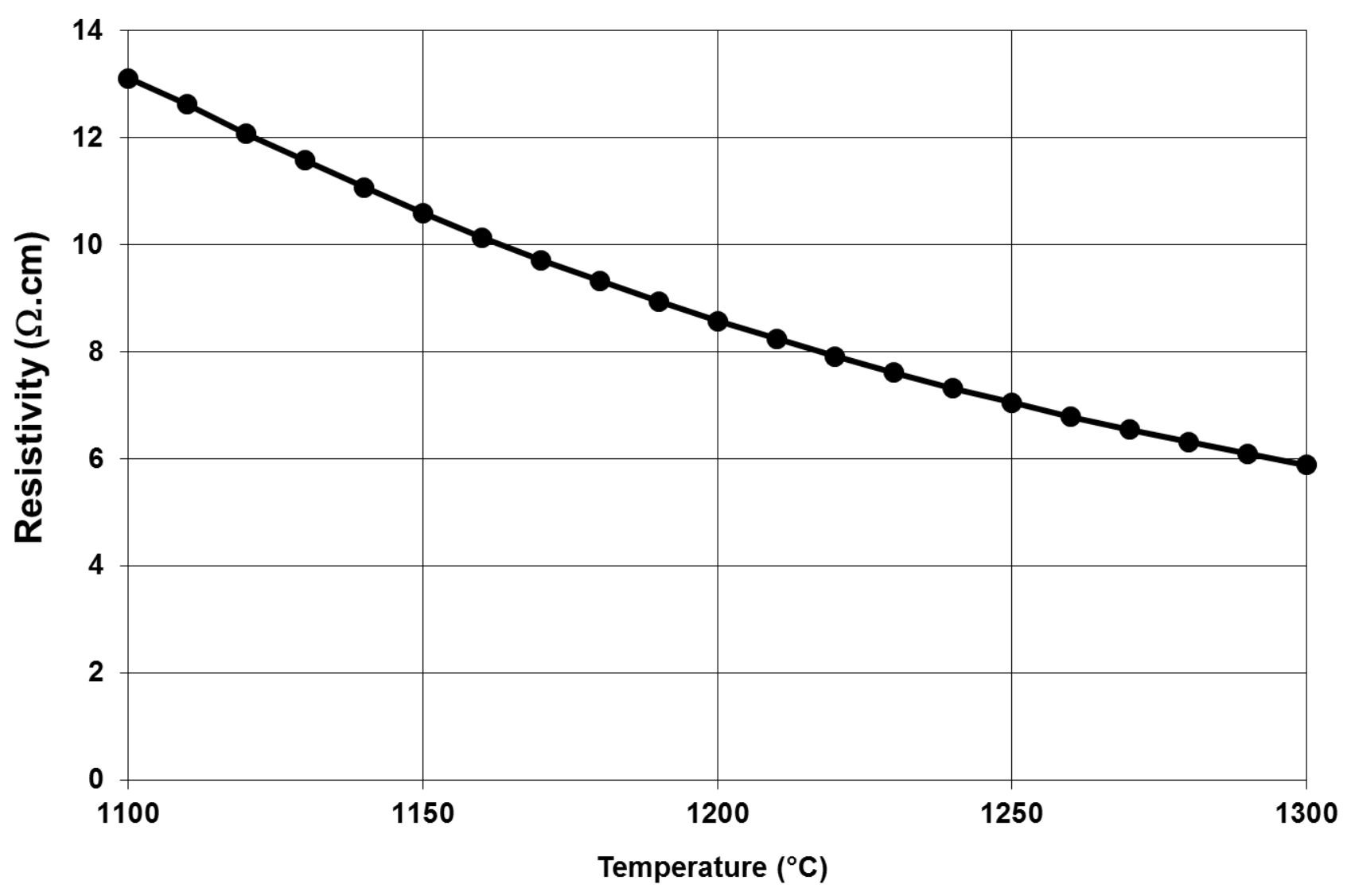

Fig. 5. Electrical resistivity of the L-UMo melt (laboratory-scale sample) as a function of temperature. 


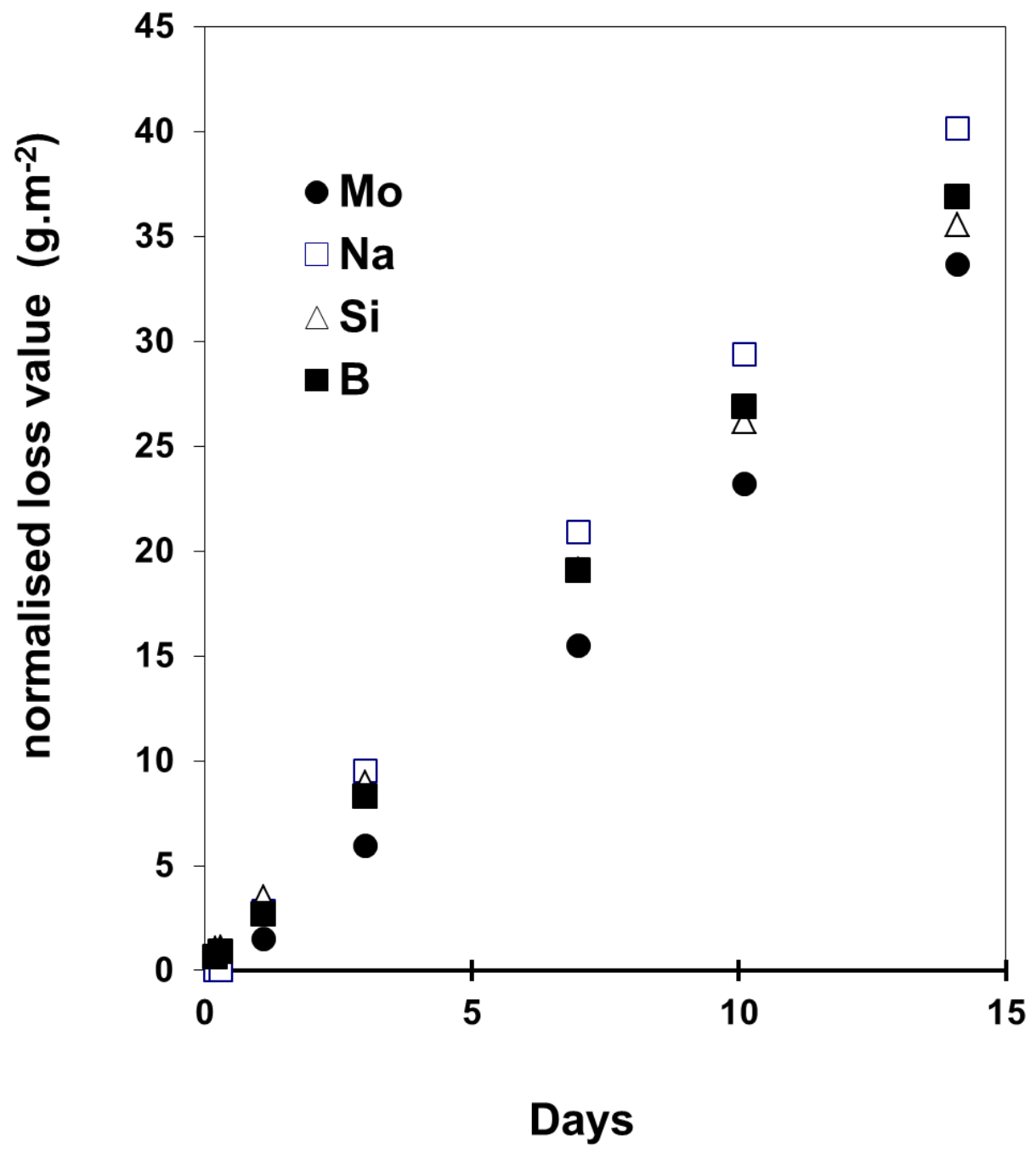

Fig. 6. Amounts of silicon, molybdenum, sodium and boron lost from a F-UMo (industrial scale) glass ceramic sample (sample 2 in Fig. 2) as a function time during a Soxhlet test at $100{ }^{\circ} \mathrm{C}$. 